\title{
High prevalence of cytomegalovirus (CMV) infection in infants born to HIV infected mothers-ANRS French Perinatal Cohort (EPF)
} Gaelle Guibert*1, Marianne Leruez-Ville2,3, Christine Rouzioux ${ }^{2,3}$, Roland Tubiana $^{4,5}$, Laurent Mandelbrot ${ }^{1,6,7}$, Stéphane Blanche ${ }^{3,8}$, JeanPaul Teglas ${ }^{1,9}$, Yassine BenMebarek ${ }^{1,10}$, Jérôme Le Chenadec ${ }^{1,9}$, Josiane Warszawski $19,10,11$ and ANRS French Perinatal Cohort (EPF)

Address: ${ }^{1}$ Inserm, U822, Le Kremlin-Bicêtre, France, F-94276, ${ }^{2}$ AP-HP, Virology Department, Necker Hospital, Paris, F-75015 France, ${ }^{3}$ EA 3620 , Univ Paris Descartes 5, Paris, France, ${ }^{4}$ AP-HP, Department of infectious diseases, Hôpital Pitié Salpêtrière, Paris, F-75651 France, ${ }^{5}$ INSERM, U543, Paris, France, ${ }^{6}$ Univ Paris 7, Paris, France, ${ }^{7}$ AP-HP, Gynecology and obstetrics department, Hôpital Louis Mourrier, Colombes, France, F-92700, ${ }^{8}$ AP-HP, Unité d'Immunologie Hématologie Pédiatrique, Necker Hospital, Paris, France, F-75015, 9INED, Paris, France, F-75020, ${ }^{10}$ AP-HP, Epidemiology department, Hopital Bicêtre, Le Kremlin-Bicêtre, France, F-94276 and ${ }^{11}$ Univ Paris-Sud, Faculté de Médecine Paris-Sud, Le KremlinBicêtre, France, F-94276

* Corresponding author

from Fourth Dominique Dormont International Conference. Host-Pathogen Interactions in Chronic Infections

Paris, France. 13-15 December 2007

Published: 9 April 2008

Retrovirology 2008, 5(SuppI I):OI0 doi:I0.II86/1742-4690-5-SI-OI0

This abstract is available from: http://www.retrovirology.com/content/5/SI/OIO

(c) 2008 Guibert et al.; licensee BioMed Central Ltd.

\section{Background}

In developed countries, $0.3 \%$ to $0.5 \%$ of all newborns are congenitally infected by cytomegalovirus (CMV) with the risk of sensorineural hearing loss or mental retardation $[1,2]$. Few results about congenital CMV infection in infants born to HIV-infected women have been reported [3]. Rate of disease progression and central nervous system disease was found to be higher in HIV-1-infected infants who acquire CMV infection in the first 18 months of life than those infected with HIV-1 alone [4]. We aimed to estimate the prevalence of neonatal CMV infection in children born to HIV-infected mothers between 1993 and 2004 enrolled in the ANRS French Perinatal Cohort (EPF).

\section{Materials and methods}

EPF is a national prospective multicenter cohort of mother-to-child HIV transmission. As part of the standardized follow-up of infants born alive between 1993 and 2004 in EPF sites, a urine sample was obtained within the ten first days of life. These samples were used to screen for congenital CMV infection, using rapid culture from 1993 to 2001 and real-time PCR since 2001.

\section{Results}

Between 1993 and 2004, 4995 of the 7878 newborns included in EPF were screened for CMV. The prevalence of CMV infection was 2.4\% (119 positive tests; 95\% confidence interval: 2.0-2.8). Thirteen of the $119 \mathrm{CMV}$ infected newborns were also infected with HIV. The prevalence of CMV infection was higher in HIV-infected newborns (10.2\%; 95\% CI: 4.9-15.5) than in HIV-uninfected newborns $(2.2 \%, 95 \% \mathrm{CI}: 1.8-2.6, \mathrm{p}<0.01)$.

\section{Conclusions}

The prevalence of congenital CMV infection was high in children born to HIV- infected mothers and was significantly higher in HIV-infected children than HIV-uninfected children.

\section{Acknowledgements}

The study was supported by the ANRS. We thank all cohort investigators and $\mathrm{V}$ Benhammou, N Chernai, A Diop, K Hamrene, P Huynh, C Laurent, M Peres, ERamos, L Boufassa, T Wack, N Zeller. 


\section{References}

I. Barbi M, Binda S, Caroppo S, Calvario A, Germinario C, Bozzi A, et al:: Multicity Italian study of congenital cytomegalovirus infection. Pediatr Infect Dis J 2006, 25:156-159.

2. Gratacap-Cavallier B, Morand P, Dutertre N, Bosson JL, BaccardLongere $M$, Jouk PS, et al: Cytomegalovirus infection in pregnant women. Seroepidemiological prospective study in I,0I8 women in Isere. J Gynecol Obstet Biol Reprod (Paris) 1998, 27:161-166.

3. Doyle M, Atkins JT, Rivera-Matos IR: Congenital cytomegalovirus infection in infants infected with human immunodeficiency virus type I. Pediatr Infect Dis J 1996, I 5: I I02-I I 06.

4. Kovacs A, Schluchter M, Easley K, Demmler G, Shearer W, La Russa $P$, et al: Cytomegalovirus infection and HIV-I disease progression in infants born to HIV-I-infected women. Pediatric Pulmonary and Cardiovascular Complications of Vertically Transmitted HIV Infection Study Group. N Engl J Med 1999, 341:77-84.

Publish with Bio Med Central and every scientist can read your work free of charge

"BioMed Central will be the most significant development for disseminating the results of biomedical research in our lifetime. "

Sir Paul Nurse, Cancer Research UK

Your research papers will be:

- available free of charge to the entire biomedical community

- peer reviewed and published immediately upon acceptance

- cited in PubMed and archived on PubMed Central

- yours - you keep the copyright

Submit your manuscript here:

http://www.biomedcentral.com/info/publishing_adv.asp 